\title{
MEDO LÍQUIDO
}

\author{
Liquid fear
}

Bauman, Z. (2008). Medo líquido. Rio de Janeiro: Zahar.

\section{Neuzi Barbarini}

Mestre em Psicologia Social e Institucional pela Universidade Federal do Rio Grande do Sul (UFRGS), Professora da PUCPR e Faculdade Dom Bosco, Curitiba,PR - Brasil, e-mail: neuzib@gmail.com

Zygmunt Bauman publica mais um livro em que utiliza o termo "líquido" para nomear questões da atualidade. Esta já é a quinta obra do autor, publicada no Brasil, que trabalha com esta idéia de liquidez, mas, neste livro, particularmente, o adjetivo mostra-se muito pertinente, pois a imagem de um medo que escorre e penetra em pequenos espaços parece ser cada vez mais presente na sociedade contemporânea.

Para Bauman, em uma sociedade "sólida", as instituições são estáveis e o indivíduo pode se apoiar nelas. Em uma sociedade líquida, os laços sociais são fluidos, incertos, as posições sociais são inseguras e a perda de referências estariam gerando medos difusos, confusos, flutuantes, principalmente pela dificuldade de estabelecimento de estratégias a longo prazo.

Nesta obra, o autor descreve três tipos básicos de perigos dos quais derivariam todos os medos. O primeiro seria os perigos que ameaçam o corpo e as propriedades, um segundo tipo, mais geral, ameaça a durabilidade da ordem social, como, por exemplo, o emprego, a segurança, por fim, os perigos que ameaçam o lugar da pessoa no mundo, sua posição social, sua identidade, ou seja, o medo da exclusão. Detalhando esses tipos de medo, ele aborda o pavor da morte ou o "medo original", o medo do mal, o horror do inadministrável e o terror global.

O medo da morte é visto pelo autor como um medo inato, endêmico, do qual não se pode fugir. Esse medo seria, provavelmente, o preço cobrado pela nossa humanidade. Ser humano é tomar consciência da morte, de sua inevitabilidade e da "apavorante tarefa de sobreviver à aquisição desse conhecimento" (p. 45).

O medo e o mal são inseparáveis como irmãos siameses e talvez até mesmo dois nomes de uma só experiência. Explorando a questão “o que é o mal?”, o autor faz a distinção entre os males naturais (como terremotos, inundações e outros desastres) e os males morais; os primeiros aleatórios e imprevisíveis e os segundos marcados pela intencionalidade ou premeditação, sendo estes representados na atualidade pelas diversas formas de extermínio praticadas principalmente no século XX e pelo terrorismo onipresente no século XXI. 
Em seguida, Bauman detalha o "horror do inadministrável", provocado principalmente pelo potencial de autodestruição alcançado pela sociedade, potencial este presente principalmente nas armas desenvolvidas e acumuladas desde a guerra fria e que já seriam suficientes para exterminar a humanidade, e elas não são as únicas a nos ameaçarem cotidianamente, pois hoje somos também responsáveis pelos males tidos como "naturais", já que muitas das catástrofes naturais são devidas ao desequilíbrio gerado pela humanidade no processo de modernização e que, embora pareça ser um mal distribuído equitativamente e de modo aleatório, até o momento a realidade tem se encarregado de desmentir essa aparência, atingindo predominantemente a população pobre. Do furacão Katrina, que dizimou prioritariamente os negros pobres de Nova Orleans, às enchentes e desmoronamentos em favelas do Brasil, vemos cada vez mais a confirmação desta tese.

Há ainda o medo do terror global, que atinge a todos por meio da globalização. Se globalização é inelutável e irreversível e tudo o que se passa em uma parte qualquer do mundo afeta a vida das pessoas no mundo inteiro, nenhum país, por mais vasto, soberano ou rico que seja, pode proteger totalmente a condição de vida, a segurança, a prosperidade, o modelo social ou a sobrevivência de seus habitantes. A globalização deixou de estar ligada somente ao capital financeiro, às comunicações e ao comércio e já se estende também à criminalidade, ao tráfico de drogas e ao terrorismo e, para provocar ainda mais medo, as forças de ação política efetivas são ainda incapazes de agir fora do âmbito local.
Bauman não acredita na possibilidade de buscar soluções locais para lutar contra os produtores globais do medo. Para ele, as saídas locais servirão sempre como paliativos, pois não estarão em condições de corrigir as conseqüências negativas da globalização. As ferramentas para a solução dos males globais não existem, precisariam ser criadas e a segurança só voltará quando a humanidade recuperar o controle sobre as forças que definem nossa condição. $\mathrm{O}$ sentimento de impotência persistirá porque "não parecemos mais estar no controle, seja sozinhos, em grupos ou coletivamente, dos assuntos de nossas comunidades, da mesma forma que não estamos no controle dos assuntos do planeta" (p. 167).

Diante deste quadro, como nos livrarmos do sentimento de impotência diante das causas de tanto medo? Para Bauman, podemos tomar medidas locais para minimizar os impactos advindos do processo mundial, como, por exemplo, promover a cooperação, a amizade e a compreensão mútua entre os cidadãos, combatendo a xenofobia, o preconceito e as desigualdades, preservando recursos naturais, como a água potável, por exemplo, proteger as áreas essenciais para a vida, como a produção de alimentos e saúde, da invasão predatória e desigual das indústrias.

Alguns leitores poderão considerar a visão de Bauman um tanto catastrofista, no entanto, concordamos quando ele diz que: "O único início promissor de uma terapia contra o medo crescente e, em última instância, incapacitante é compreendê-lo, até o seu âmago - pois a única forma promissora de continuar com ela exige que se encare a tarefa de cortar essas raízes" (p. 229). 